\title{
Belarus, Crimea and the Donbas: Belarusian attitudes to the post-maidan events in Ukraine
}

Journal of Contemporary Central and Eastern EuropeVolume 28, Issue 1, 2 January 2020,

Pages 85-91

Belarus, Crimea and the Donbas: Belarusian attitudes to the post-maidan events in Ukraine(Article)

- Mudrov, S.A.

- Department of Social Communications, Polotsk State University, Navapolatsk, Belarus

Краткое описание

This essay discusses the attitudes in Belarus towards the incorporation of Crimea into the Russian Federation and the war in the Donbas region. In general, Belarusian authorities refused to recognize Crimea as a part of Russia, and continue to consider this peninsula to be de jure a part of Ukraine. The war in the Donbas is seen more as a civil war than as a "Russian aggression" although the involvement of Russia is not denied. At the same time, the general public in Belarus justifies the incorporation of Crimea into the Russian Federation and believes that the Ukrainian authorities are most at fault for their inability to stop the war in the Donbas. (c) 2020 Informa UK Limited, trading as Taylor \& Francis Group. 
https://www.scopus.com/record/display.uri?eid=2-s2.0-

85089393910\&doi=10.1080\%2f25739638.2020.1807732\&origin=inward\&txGid=15de8e46e665c5e8 ba1fb63874b42c2c 